\title{
Examining the Moderating Role of Job Satisfaction in the Relationship Between Job Insecurity and Workplace Psychological Stress
}

\author{
Saif-ud-Din \\ Assistant Professor \\ Human Resource Management, College of Business-Rabigh, \\ King Abdul-Aziz University, Kingdom of Saudi Arabia
}

\begin{abstract}
The purpose of this study is to analyze the moderating role of job satisfaction between job insecurity and job stress among the engineers of Pakistani based multinational company. Data was collected from a sample of 173 respondents through a questionnaire. A significant correlation was found among all the research variables. Hierarchical moderated regression is used to measure the moderating role of job satisfaction. Results showed an interaction effect of job satisfaction and job insecurity on the dependent variable job stress. The study proved that the relationship between job insecurity and job stress was low when job satisfaction was high, however, low job satisfaction among the employees exacerbate this relationship. The generalization of the result is limited being a single organization wherein the research was conducted. The findings show the importance of job satisfaction for the management as a tool to mitigate the negative feelings of job insecurity among the employees. Implications and future research directions are discussed.
\end{abstract}

Keywords: Job Insecurity, Job Satisfaction, Job Stress,

DOI: $10.7176 / \mathrm{EJBM} / 11-6-01$

\section{Introduction}

Over the past several decades working life has been subject to dramatic change, for example changes in career structures and work life environment, including the role of women in modern workforce, technological advancement, changes in labor laws, work process automation, and the aging workforce (Macky, 2004). Job insecurity is considered as a serious work stressor in the modern work environment, with negative work related outcomes (Jiménez, Milfelner, Šarotar, Žižek, and Dunkl, 2017). The concept of job security during 1960's to 70's has been shifted from a motivator factor to potential stressor as job insecurity in 1980's (Greenhalgh and Rosenblatt, 1984; Sverke, Hellgren, and Näswall, 2006). Greenhalgh and Rosenblatt (1984) define job insecurity as 'the perceived powerlessness to maintain desired continuity in a threatened job situation'. We noted that, increased feelings of security over time have negatively prolonged effects on workers depression levels (Rocha, Crowell, and McCarter, 2006). Given that, job insecurity in modern working life considered as the most significant stressors at the workplace (DeCuyper, Bernhard, Berntson, DeWitte, and Alarco, 2008). Selye (1978) elaborated stress as a force, strain or pressure, applied upon an object or an individual who resists these forces and efforts to hold their usual condition. Stress may be experienced when an employee expects to lose their resources at the workplace (Hobfall, 1989).

It was noted that, work stressors in different job related scenario have significant negative influence on employee health and well-being and strain in such situation is the employees' physiological and psychological reaction to such condition (Holmstrom, 2008). Locke (1976) on the other hand threw a light on overall job satisfaction as 'an enjoyable and optimistic emotional condition appearing due to the appraisal of employees' job or job experiences'. Job insecurity as noted above is the strong predictor of psychological stress among the workforce which contributes towards emotional exhaustion, coworkers relationship issues, and low physical health (Jahoda, 1982). Job insecurity is associated with adverse reactions by employees especially in term of reduced job satisfaction (Ritcher, 2011). An attainment of the pleasures at workplace is an art of coping with stress (Rizwan, Tariq, Hussain, Rashid, Hussain, and Khawar, 2013). This study contributes to understand the development of this relationship by providing insights into what stressor like job insecurity impact job stress and how job satisfaction mitigates job stress in the working environment among a sample of industrial professionals.

\section{Literature Review}

Greenhalgh and Rosenblatt (1984) explored job insecurity for the first time and asserted that job insecurity is a condition where a person's perceived powerlessness to preserve continuity of threatened job condition. Other researchers considered job insecurity as "the subjectively experienced anticipation of a fundamental and involuntary event” (Sverke, Hellgren, and Näswall, 2002, p. 243). Therefore, job insecurity predicts the discontinuation of ones job in a threatened situation having the characteristics of uncertainty about the future. Job insecurity has become a more frequently researched stressor in modern working life almost in every organization (Yasliaglu, Karagulli, and Baran., 
2013). It was observed that perception of job insecurity grew up in most of the European countries during the last five years (De Witte., 2005), however, research in non-western collectivistic settings are leg behind. In the context of Pakistan cross sectional study proved that job insecurity has a negative influence on job satisfaction, employee performance, organizational commitment and intention to quit (Qureshi and Khan, 2016).

Researchers explored job insecurity as a source of affecting mental health and employee's well-being which negatively influence job satisfaction (Mauno, Leskinen and Kinnunen, 2001). Moreover, job insecurity literature shows different results in a different work situation, for example, attitudinal, behavioral and health related outcomes (Hartley, Jacobson, Klandermans, and van Vuuren., 1991; Sverke, Hellgren, and Näswall, 2002). Moreover, it was asserted that 'job insecurity is derived from objective threats via individual cognitive processes' (Sverke, et. al., 2002). Almost, in every organization, the reason of employee exhaustion is job stress and hopelessness among the employees (Huarng, 2001). People gain their psychological stress due to job insecurity and more work demands than their capacity as well as demanding pace of life (Rizwan et al., 2013). Studies conducted by different researchers found negative relationship between job insecurity and job satisfaction (Clark, 2005; Reisel, Probst, Chia, Maloles, and Konig, 2010; Richter, 2011). Job satisfaction is considered as the most common and widely researched attitudinal outcomes of the job insecurity (Sverke, 2002). It was also explored that, employees who feels unsecured in their jobs experience lower job satisfaction (Ashford, Lee, and Bobko, 1989).

A study conducted by Brewer and McMahan-Landers (2003) explored negative correlation between job stress and job satisfaction. Other researchers asserted that job insecurity has negative influence on job stress (Yasliaglu, Karagulli, and Baran., 2013). Similarly employees who experience uncertainty and instability in their job feel lower job satisfaction (Rizwan et al., 2013; Mansoor., Fida., Nasir., and Ahmad., 2011). This study is an attempt to examine job satisfaction as a moderator in relationship between role stressor-job insecurity and psychological stress. It was noted that psychological stress and job satisfaction has inverse relation with job satisfaction meaning that those individual who feel higher stress level experience low job satisfaction (Abouserie, 1996).

In recent past researchers also used the pervasive role of job satisfaction in organizational studies as a moderator and mediator in different behavioral and attitudinal outcomes, for example the moderating role of job satisfaction in servant leadership and turnover intention relationship among the Turkish employees (Turgut, Bekmezci, Ateş, 2017). Conservation of resource theory (Hobfoll, 1989) guide us that, if organizational workplace demands are higher than the individuals resources (mental and physical), in turn threaten individual well-being and negative organizational outcomes for example, job stress, job dissatisfaction and low organizational commitment. Therefore we argue that, if organization properly manage and invest in their human resource, in turn, improve job satisfaction level among the employees which can be used as a coping mechanism to reduce stress level among the employee due to job insecurity. Therefore, we expect that, employee who experience high job satisfaction likely mitigate the relationship of job insecurity and psychological job stress.

\subsection{Theoretical Framework and Hypothesis}

After going through the literature review, the proposed model of research paper is given below 
Figure: 1

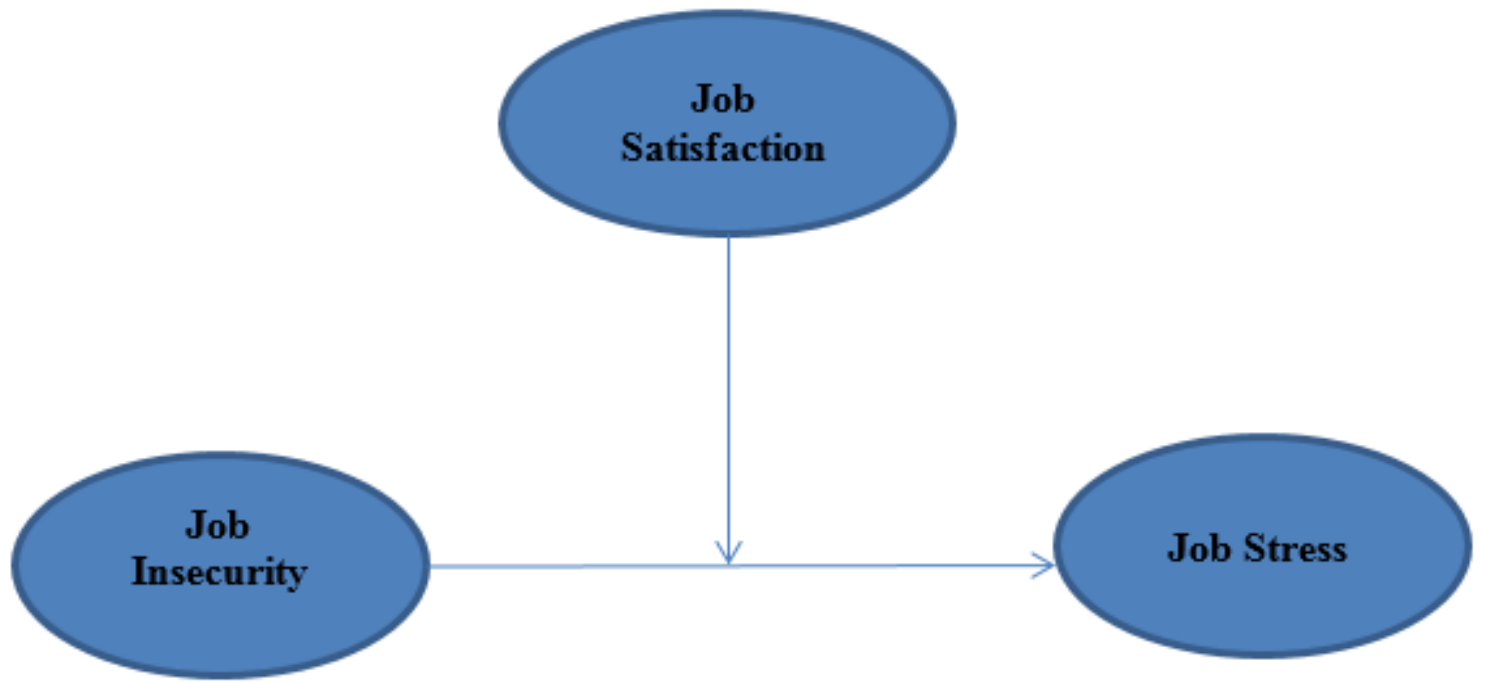

Hypothesis:

H1: All the research variables are significantly correlated.

H2: Job insecurity is a significant negative predictor of job stress.

H3: Job satisfaction moderates the relationship between job insecurity and job stress, such that, the individuals with low job satisfaction experience high job stress and individual with high job satisfaction experience low job stress.

\section{Research Methodology}

\subsection{Survey approach}

As surveys are good for measuring orientations and attitudes for large population, so survey approach is applied (Sekaran, 1999). Researches show that for data gathering survey approach is the frequently and commonly used approach in the social sciences (Babbie, 1993). Considering these facts, in this study the survey approach was applied with the implementation of a structured questionnaire among 180 employees of the organization.

\subsection{Population and sampling}

The employees working in Pakistani based multinational company were the population of this research project. A pilot study was carried out for having the statistical error in the information provided by the respondents; the outcomes of the pilot study were put in the formula for testing of questionnaire, verification of the variables, sample selection and creation of hypotheses. A sample of 78 employees was derived utilizing the formula for the selection of sample size from finite population. Krejcie \& Morgan (1970) tabulated 175 samples for 320 population size. Moreover, low response was expected so, keeping in view above factors, 180 copies of the questionnaire were distributed to the employees excluding those respondents who were included in the pilot study. The questionnaire was distributed among 180 employees and a number of 173 questionnaires were received and the response rate was $97 \%$.

\subsection{Sampling}

Normally, convenience sampling is used for the speedy collection of many numbers of completed surveys with economy (Rizwan et al., 2013). Adenike (2011) asserted that most studies that have already been conducted used convenience sampling technique because it would be difficult for researchers to have access every unit of sample. Considering the fact of these findings, the researcher used convenient sampling technique. 


\subsection{The demographics result is shown in table 1}

Table 1:

\begin{tabular}{|c|c|c|}
\hline Category & Frequency & Percent \\
\hline Gender & & \\
\hline Female & 0 & 0 \\
\hline Male & 173 & 100 \\
\hline \multicolumn{3}{|l|}{ Designation } \\
\hline Manager & 6 & 3.5 \\
\hline Asstt Manager & 15 & 8.7 \\
\hline Engineer & 35 & 20.2 \\
\hline Sub Engineer & 62 & 35.8 \\
\hline Helper & 37 & 21.4 \\
\hline Other & 18 & 10.4 \\
\hline \multicolumn{3}{|l|}{ Age } \\
\hline $18-25$ & 41 & 23.7 \\
\hline $26-35$ & 56 & 32.4 \\
\hline $36-45$ & 58 & 33.5 \\
\hline $46-55$ & 16 & 9.2 \\
\hline$\geq 55$ & 2 & 1.2 \\
\hline \multicolumn{3}{|l|}{ Experience } \\
\hline$<5$ & 95 & 54.9 \\
\hline $5-10$ & 40 & 23.1 \\
\hline $11-16$ & 27 & 15.6 \\
\hline $17-22$ & 7 & 4.0 \\
\hline $23-28$ & 4 & 2.3 \\
\hline$>28$ & 0 & 0 \\
\hline \multicolumn{3}{|l|}{ Qualification } \\
\hline Undermatric & 11 & 6.4 \\
\hline Matric (Grade 10) & 32 & 18.5 \\
\hline FA/FSc. (Grade 12) & 11 & 6.4 \\
\hline Diploma (Grade 12) & 62 & 35.8 \\
\hline Master (other than Engineering) & 4 & 2.3 \\
\hline Engineering & 53 & 30.6 \\
\hline \multicolumn{3}{|l|}{ Department } \\
\hline Safety & 5 & 2.9 \\
\hline Electrical & 32 & 18.5 \\
\hline Civil & 66 & 38.2 \\
\hline Mechanical & 41 & 23.7 \\
\hline Chemical & 8 & 4.6 \\
\hline Admin & 3 & 1.7 \\
\hline Other & 18 & 10.4 \\
\hline
\end{tabular}

In table 1, demographic information reveals that all the respondents were male. The manpower consisted most of the sub-engineers, engineers and helpers. The average age of the respondents was 35 years old. Maximum employees have less than 5 years' experience. Profession wise the most of the manpower consisted of diploma holders and engineers, respectively. Similarly most of the employees were working in civil, mechanical and electrical divisions.

\subsection{Instrumentation}

The survey techniques through a structured questionnaire were used as an instrument of data collection consisting of two parts. Part A dealt with the demographics information of the respondents while Part B dealt with the research variables i.e. job insecurity, job stress and job satisfaction.

For job insecurity, the 20 -items short version of the original 57 -items scale was used originally developed by Ashford at el., (1989), measured on 5-point Likert type scale. The obtained Cronbach's alpha was .84 for this scale. Job Stress Scale developed by Parker \& Decotiis (1983) was used with thirteen items measured on 5-point Likert 
type scale and secured .79 value of Cronbach's alpha. Job satisfaction was measured by Gul and Oktay (2009) inventory that used fourteen items Likert type scale having $1=$ least satisfactory to $5=$ Most satisfactory for the identification of the Job satisfaction of the respondents of the organization understudy. The obtained Cronbach's alpha from this inventory was .79. Therefore, all the measures were in acceptable level to use for analysis in this study.

\section{Results}

\subsection{Testing of hypothesis 1}

Table 2: Means, standard deviation, and correlations

\begin{tabular}{|c|c|c|c|c|c|}
\hline Variables & JI & JS & JSF & Mean & Std. Deviation \\
\hline JI & 1 & & & 2.8908 & .44238 \\
\hline JS & $.596^{* *}$ & 1 & & 3.3433 & .47379 \\
\hline JSF & $-.451^{* *}$ & $-.511^{* *}$ & 1 & 4.0710 & .36685 \\
\hline$* * \mathrm{P}<0.01$
\end{tabular}

Table 2 shows that all the variables are significantly correlated. As depicted in table 2, job insecurity and job stress are significantly and positively correlated. Moreover, job insecurity and job satisfaction are also negatively correlated as expected. Mean values in table 2 shows that employees of the organization understudy were satisfied strongly with their job $(M=4.1)$ and were also having neutral job stress $(M=3.3)$.

\subsection{Testing of hypothesis 2}

Table 3:

\begin{tabular}{|l|c|c|c|c|c|}
\hline $\begin{array}{l}\text { Model } \\
F=94.17, P=.000\end{array}$ & \multicolumn{2}{|c|}{ Unstandardized Coefficients } & Standardized Coefficients & \multirow{2}{*}{ Sig. } \\
\cline { 2 - 4 } & $\mathrm{B}$ & Std. Error & Beta & \\
$R^{2}=.35$ & & & & \\
\hline Constant & 1.498 & .192 & .596 & 9.790 & .000 \\
Job Insecurity & .638 & .066 & 9.705 & .000 \\
\hline
\end{tabular}

a. Dependent Variable: Job Stress

The standardized beta value $(\beta=.596, p=.000)$ in table 3 confirmed that job insecurity predicting job stress, $\mathrm{R}^{2}$ value also shows that $35 \%$ change in job stress is significantly counted by job insecurity, hence $H 2$ is accepted.

\subsection{Testing of hypothesis 3}

Table 4: $\quad$ Results of the moderated hierarchical regression analysis

\begin{tabular}{|c|c|c|c|c|c|}
\hline \multicolumn{2}{|l|}{ Model } & B & $\mathrm{T}$ & $\mathrm{R}^{2}$ & $\Delta \mathrm{R}^{2}$ \\
\hline Step 1 & Job Insecurity & .638 & $9.705 * *$ & $.355^{* *}$ & -- \\
\hline \multirow{2}{*}{ Step 2} & Job Insecurity & .492 & $7.070 * *$ & \multirow{2}{*}{$.429 * *$} & \multirow{2}{*}{$.074 * *$} \\
\hline & Job Satisfaction & -.392 & $-4.680 * *$ & & \\
\hline \multirow{3}{*}{ Step 3} & Job Insecurity & .477 & $6.884 * *$ & \multirow{3}{*}{$.442 * *$} & \multirow{3}{*}{$.013 * *$} \\
\hline & Job Satisfaction & -.407 & $-4.878 * *$ & & \\
\hline & $\begin{array}{ll}\text { Job Insecurity } \times \quad \text { Job } \\
\text { Satisfaction }\end{array}$ & -.344 & $-1.991^{*}$ & & \\
\hline
\end{tabular}

In step 1, (table 4), job insecurity was regressed on job stress, in step 2, the moderator was added in the equation and in step 3, interaction term consisting job insecurity and job satisfaction was added in the equation which produced significant result. Before testing the hypothesis all the independent and moderated variables were centered to follow the protocol of the interaction analysis. The result of moderated hierarchical regression is available in table 4 which shows significant moderation effect of job satisfaction between job insecurity and job stress. In step 3 the interaction effect is significant where $(\mathrm{B}=-.344, P<.001)$ and change in $\mathrm{R}^{2}\left(\Delta \mathrm{R}^{2} .013, P<0.001\right)$ after inclusion of interaction term. Moreover, below figure 2 depicted that, employee with low job satisfaction experience high level of psychological stress, however, when they are high in job satisfaction experience low psychological stress produced by job insecurity. So, the relationship of job insecurity and job stress is moderated by job satisfaction subject to low or high job satisfaction. Thereby, hypothesis 3 was accepted. 
Figure 2: Graphical representation of moderating effect of job satisfaction

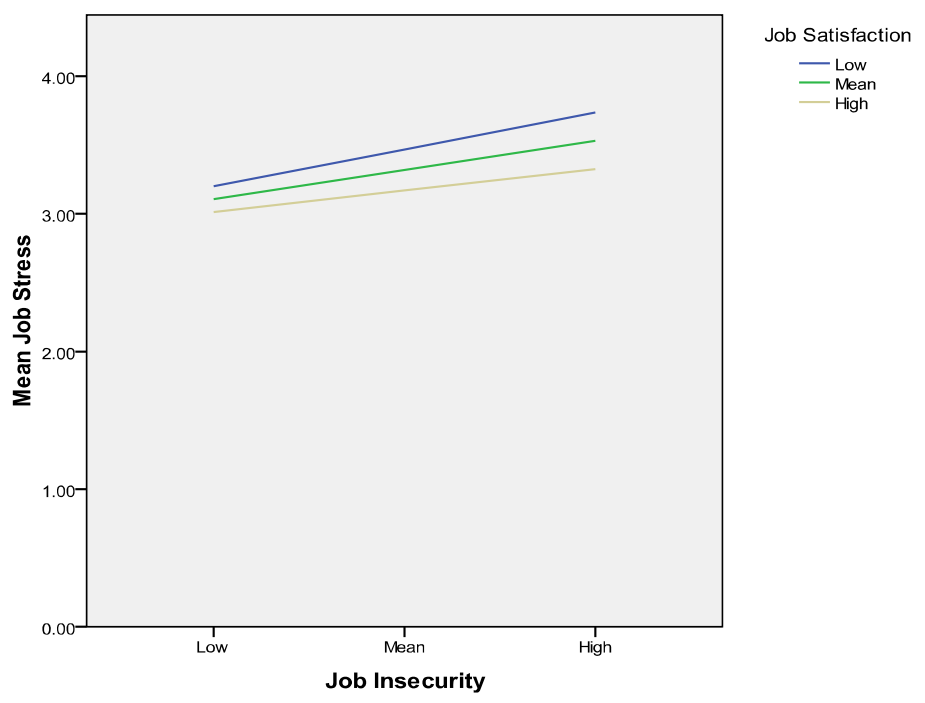

\section{Discussion}

The primary goal of this study was to find the moderating effect of job satisfaction in job insecurity and job stress relationship. The impact of job insecurity on job stress was significantly positive which is in line with the previous study conducted by Yaslioglu et al., (2013). In addition, the model indicated that all the independent and dependent variables are correlated where job satisfaction is negatively related with job insecurity and job stress, while the relationship between job stress and job insecurity was significantly positive. Further, results found that this positive link between job insecurity and job stress was moderated by job satisfaction and those who report high job satisfaction are less affected by job insecurity. The results of previous studies revealed that job insecurity lead towards higher job stress (e.g., Yasliaglu et al., 2013) and job satisfaction negatively related with job stress (Ahsan, Abdullah, Fie, and Alam., 2013; Khattak, Ain, and Iqbal., 2013; Mansoor et al., 2011; Rizwan et al., 2013). The effect of job insecurity on job stress was moderated by job satisfaction depicted in table 4 . The most upper line shows low job satisfaction and at this point the job stress is high caused by increased perception of job insecurity and the most lower line depicts high job satisfaction and we observed in this stage that, employees perceive low job stress caused by increased perception of job insecurity.

\subsection{Conclusions \& Recommendations}

The result confirmed that job satisfaction plays an important role in moderating the effect of job insecurity on employee's job stress. The management should provide an environment in which employees, especially those who are not permanent or likely not to be permanent in near future, may work satisfactorily which will reduce the impact created by job stress due to their feeling of insecurity in their respective jobs. The organization need to implement HR practices to motivate them and ensure their job security, thereby improve their morale and most importantly provide them good career development opportunities. This will ultimately improve the satisfaction level and job performance as well organizational productivity. The challenging environment throughout the globe needs to provide job security to make their organization more productive.

\subsection{Limitation and Future researches}

The study include only one stressor job insecurity causing stress, in future other job stressors like different role stressors may be included to explore the impact of other variables. Likewise job stress more outcomes of the job insecurity may be explored, for example turnover intension, emotional exhaustion, job performance, and organizational commitment. In addition, due to the time, budget and accessibility constraints the researcher could not collect data from many organizations therefore; more companies may be included to increase the sample sized in order to generalize the findings and to ensure more heterogeneous sample. Single source of data is also the major limitation of this study so, it is recommended to collect a data from multiple sources.

\section{References}

1. Abouserie, R. (1996) 'Stress, Coping Strategies and Job Satisfaction in University Academic Staff', Educational Psychology, 16(1), 49-56.

2. Adenike, A. A. (2011) 'Organizational climate and job satisfaction among academic staff in some selected private universities in Southwestern Nigeria', (Unpublished Dissertation), Covenant University, OTA Ogun State: Nigeria. 
3. Ahsan, N., Abdullah, Z., Fie, G. Y. D., \& Alam, S. S. (2009) 'A study of job stress on job satisfaction among university staff in Malayisa: Empirical study’, European Journal of Social Sciences. 8(1), 121-131.

4. Ashford, S. J., Lee, C. \& Bobko, P. (1989) 'Content, cause, and consequences of job insecurity: A theory based measure and substantive test', Academy of Management Journal, Vol. 32, 803-829.

5. Babbie, R. (1993). Research methods for social work. USA: Cengage

6. Brewer, E.W. and J. McMahan-Landers. (2003) 'Job satisfaction among industrial and technical teachers educators', Journal of Career and Technical Education, vol, 40: 28-36.

7. Clark., J.L. (2005) 'Moderators of the Effects of Job Insecurity', (Unpublished Dissertation). Queens University of Technology: Australia.

8. De Witte., H. (2005) 'Job Insecurity: review of the international literature on definitions, Prevalence, antecedents and consequences, SA Journal of Industrial Psychology, 31(4), 1-6

9. DeCuyper, N., Bernhard, C., Berntson, E., DeWitte, H., \& Alarco, B. (2008) 'Employability and employeese well-being: mediation by job insecurity', Applied Psychology: An international review, 7(3), 488 - 509.

10. Greenhalgh, L., and Rosenblatt, Z. (1984) 'Job insecurity: Toward conceptual clarity', Academy of Management Review, 3, 438-448.

11. Gul, H., \& Oktay.E. (2009) 'Relations between Pay, Career, Job Satisfaction and Performance: An Application in Karaman Governorship', Selçuk Üniversitesi Sosyal Bilimler Enstitüsü Dergisi. Pp:223-238.

12. Hartley, J., Jacobson, D., Klandermans, B., \& van Vuuren, T. (1991) 'Job insecurity: Coping with jobs at risk', London: Sage.

13. Hobfoll, S.E. (1989) 'Conservation of resources: A new attempt at conceptualizing stress, American Psychologist, 44(3), 513-524.

14. Holmstrom, S. (2008) 'Workplace stress measured by Job Stress Survey and relationships to musculoskeletal complaints', (Doctoral Dissertation): Umea, Sweden.

15. Huarng, A.S. (2001) 'Burnout syndrome among information system professionals', Information Systems Management, Vol.18 No.2, 15-20.

16. Jahoda, M. (1982). Employment and unemployment, A social psychological analysis. Cambridge: Cambridge University Press.

17. Jiménez, P., Milfelner, B., Šarotar Žižek, S., and Dunkl, A. (2017), 'Moderating Effects between Job Insecurity and Intention to Quit in Samples of Slovene and Austrian Workers', Naše gospodarstvo/Our Economy, 63(1), 27-37.

18. Khattak, M.A., Ain., and Iqbal, N. (2013) 'Impact of Role Ambiguity on Job Satisfaction, Mediating Role of Job Stress', International Journal of Academic Research in Accounting, Finance and Management Sciences, 3(3), 28-39.

19. Krejcie, R. V., and Morgan, D. W. (1970) 'Determining sample size for research activities' Educational and psychology measurement, Vol. 30, 607-610.

20. Locke, E.A (1976) 'The Nature and Causes of Job Satisfaction. In M.D Dunnette (Ed), Handbook of Industrial and organizational Psychology.

21. Macky, K. (2004) 'Organizational downsizing and redundancies: The New Zealand workers experience', New Zealand Journal of Employment Relations, 29(1), 63- 87.

22. Mansoor, M., Fida, S., Nasir, S., and Ahmad, Z. (2011) 'The impact of job stress on employee job satisfaction A study on Telecommunication sector of Pakistan' Journal of business studies Quarterly, 2(3), 50-56.

23. Mauno, S., Leskinen, E., \& Kinnunen, U. (2001) 'Multi-wave, multivariable models of job insecurity: Applying different scales in studying the stability of job insecurity', Journal of Organizational Behavior, 22, 919-937.

24. Parker, D. F., Decotiis, A. T. (1983) 'Organizational Determinants of Job Stress', Organization Behavior and Human Resources, Vol.32, 167-177.

25. Qureshi, M.A., and Khan, M.A., (2016) 'Organizational and psychological outcomes of job insecurity: A cross sectional investigation in the private sector organizations of Pakistan using subjective approach of job insecurity', Pakistan business review, 18(1), 19-36.

26. Reisel, W. D., Probst, T. M., Chia, Maloles, C. M., \& Konig, C. J. (2010) 'The effects of job insecurity on job satisfaction, organizational citizenship behavior, deviant behavior, and negative emotions of employees', International Studies of Management and Organization, 40(1), 74-91.

27. Richter, A. (2011) 'Job insecurity and its consequences, investigating moderator, mediator and gender', (Unpublished Dissertation), Stockholm University: Sweden.

28. Rizwan, M., Tariq, M.A., Hussain, S., Rashid, R.M., Hussain, M.S. \& Khawar, I.H. (2013) 'Antecedents of job stress and its impact on job satisfaction', Asian Journal of Empirical Research, 3(2), 175-190.

29. Rocha, C., Crowell, J.H., and McCarter, A.K. (2006) 'The Effects of Prolonged Job Insecurity on the Psychological Well-Being of Workers', The Journal of Sociology \& Social Welfare: 33(3), 9-28.

30. Sekaran, U. (1999) 'Research methods for business', John Wiley \& Sons

31. Seyle, H. (1978). The Stress of Life, (2nd ed.). New York: McGraw-Hills. 
32. Sverke, M., Hellgren, J., \& Näswall, K. (2002) 'No security: A meta-analysis and review of job insecurity and its consequences', Journal of Occupational Health Psychology, 7, 242-264.

33. Turgut., H., Bekmezci M., Ateş, M.F. (2017) 'The Moderating Role of Job Satisfaction on the Relationship between Servant Leadership and Turnover Intention, journal of business research Turk,9(2), 300-314.

34. Yasliaglu, M., Karagulli, A.O. \& Baran, M. (2013) 'An Empirical Research on the Relationship between Job Insecurity, Job Related Stress and Job Satisfaction in Logistics Industry', Preocedia Behavioral and Social Sciences, Vol. 9, 332338. 